\title{
SISTEM INFORMASI GEOGRAFIS PENCARIAN LOKASI AGEN BUS DAN TRAVEL TERDEKAT DI KOTA SEMARANG BERBASIS MOBILE DENGAN METODE DIJKSTRA
}

\author{
M. Rizki Kurniawan. ${ }^{1)}$, Oky Dwi Nurhayati ${ }^{2)}$, Kurniawan Teguh Martono' \\ Program Studi Sistem Komputer, Fakultas Teknik, Universitas Diponegoro \\ Jalan Prof. Sudharto, Tembalang, Semarang, Indonesia \\ E - mail : risknoscale@gmail.com
}

\begin{abstract}
Nowadays, the mobility of people who travel to a place through road transportation is increasing, either private vehicle or public transportation services. By the high intensity of use the road transportation, especially the road transportation service in Semarang, in this cases are bus and travel, it makes the transportation service users often confused in determining transportation agency to be used, especially if user is in hurry. Therefore, transportation user need a mobile application that can provide bus or travel transportation agency locator services which nearby user location and provide destination route which is expected. The Bus and Travel agency - Based Applications Mobile Locator Using Dijkstra Method is the ultimate solution in the search of bus and travel agency in Semarang. The purpose of development this application is developing a search guidance system of bus and travel agency location which nearby user location that can provide an efficient route and save the time.

The Bus and Travel agency - Based Applications Mobile Locator is implemented using ionic framework that runs on Android. Sqlite as the media storage of this, allows user to perform agency data management. In Addition, it is supported by the relevance of agency data which is obtained from Department of Transportation, Communication, and Information Central of Java and transportation magazine site.

The use of Google Maps API supports search location using Dijkstra Method in search of bus and travel agency, that expected to facilitate the users find travel or bus agency as expected, and its information that's already available.
\end{abstract}

Keywords: Android, Sqlite, Google Maps API, Ionic Framework, Dijkstra

\section{PENDAHULUAN}

\section{A. LATAR BELAKANG}

Era teknologi informasi saat ini mengalami perkembangan yang pesat. Faktor ketersediaan informasi dan kemudahan pengguna dalam mengakses informasi dimana dan kapanpun inilah yang menjadikan pemanfaatan teknologi informasi diterapkan hampir dalam semua bidang. Salah satu teknologi yang dapat dimanfaatkan untuk mengatasi hal ini adalah penggunaan teknologi nirkabel.Tidak terkecuali dalam menyajikan sebuah peta atau rute, dengan memanfaatkan teknologi nirkabel, dapat dikembangkan sistem informasi geografis berbasis mobile.
Saat ini banyak orang - orang yang berpergian baik menggunakan kendaraan pribadi maupun memanfaatkan layanan transportasi umum. Dengan tingginya mobiltas orang - orang yang berpergian ini, khususnya pengguna layanan transportasi umum di wilayah kota semarang, dalam hal ini transportasi bus dan travel, tentunya pengguna membutuhkan sebuah perangkat lunak mobile yang dapat memberikan layanan pencarian agen transportasi bus atau travel yang menyediakan rute perjalanan yang diinginkan. Pembuatan perangkat lunak ini diharapkan akan menjadi solusi yang dapat digunakan oleh pengguna layanan ini sebagai penunjuk jalan untuk meningkatkan efisiensi pencarian rute agen terdekat dari lokasi perangkat pengguna di wilayah kota semarang memanfaatkan metode pencarian Dijkstra.

\section{B. RUMUSAN MASALAH}

Bagaimana menciptakan sebuah sistem informasi geografis berbasis mobile yang user friendly dan dapat membantu pengguna dalam melakukan pencarian rute tujuan agen travel atau bus terdekat di wilayah kota semarang dari lokasi perangkat pengguna?

\section{BATASAN MASALAH}

Dalam penulisan tugas akhir ini, penulis membatasi pembahasan masalah sebagai berkut :

1. Sistem operasi perangkat pengguna menggunakan Android (4.0 atau lebih) yang mempunyai fitur GPS.

2. Sistem diimplementasikan menggunakan Ionic framework.

3. Algoritma yang digunakan adalah Algoritma Djikstra.

4. Menggunakan Google Maps JavaScript API v3 sebagai library peta yang digunakan dalam pengembangan.

5. Sistem hanya memuat agen transportasi bus dan travel untuk wilayah kota semarang

6. Agen transportasi yang dijadikan objek penelitian adalah agen transportasi bus AKAP dan agen Travel yang melayani pemberangkatan dari lokasi agen berada

7. Rute keberangkatan agen berasal dari wilayah Semarang

D. TUJUAN MASALAH

1. Membantu pengguna dalam pencarian rute agen travel atau bus terdekat sehingga diharapkan dengan perangkat lunak ini dapat memberikan rute yang efisien dan menghemat waktu

2. Menciptakan dan mengimplementasikan sebuah perangkat lunak sistem informasi geografis berbasis mobile 


\section{TINJAUAN PUSTAKA}

\section{A. SISTEM INFORMASI GEOGRAFIS}

SIG sebagai sistem komputer yang digunakan untuk memanipulasi data geografi. SIG mempunyai kemampuan untuk menghubungkan berbagai data pada suatu titik tertentu di bumi, menggabungkannya, menganalisa, dan akhirnya memetakan hasilnya. Data yang diolah pada SIG adalah data spasial yaitu sebuah data yang berorientasi geografis dan merupakan lokasi yang memiliki sistem koordinat tertentu, sebagai dasar referensinya. Sehingga aplikasi SIG dapat menjawab beberapa pertanyaan seperti lokasi,kondisi, tren, pola dan pemodelan. Kemampuan inilah yang membedakan SIG dengan sistem informasi lainnya. SIG dapat diuraikan menjadi beberapa subsistem, seperti yang telihat pada Gambar 1 berikut.

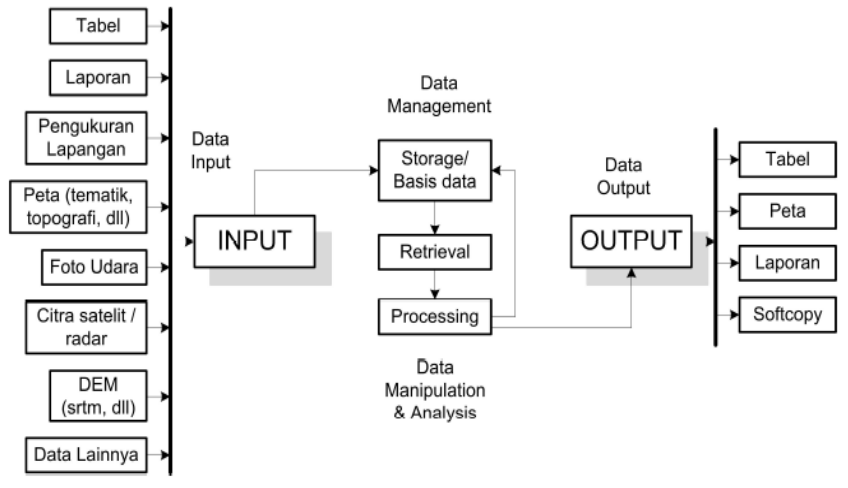

Gambar 1 Ilustrasi Uraian Sub - sistem SIG

\section{B. GPS (Global Positioning System)}

Global Positioning System (GPS) adalah suatu sistem radio navigasi penentuan posisi menggunakan satelit. GPS dapat memberikan posisi suatu objek di muka bumi dengan akurat dan cepat (koordinat tiga dimensi $\mathrm{x}, \mathrm{y}, \mathrm{z}$ ) dan memberikan informasi waktu serta kecepatan bergerak secara kontinyu di seluruh dunia.

\section{PERANGKAT BERGERAK}

Menurut Gartner (2003), perangkat bergerak secara umum dapat diklasifikasikan dalam 2 kategori, yaitu :

[1]. Telepon selular dengan peningkatan kemampuan komputasi, termasuk menampilkan grafik dan kemampuan berinteraksi dengan grafik (seperti : smartphone dan communicator).

[2]. Komputer portable, yang dapat diitegrasikan dengan kemampuan komunikasi audio - video (seperti : PDA, dan lain - lain).

Pada Umumnya perangkat bergerak yang digunakan untuk aplikasi klien kartografi memiliki sistem operasi, yang memberi pengguna sebuah antarmuka dan control sinkronisasi perangkat. Terdapat beberapa sistem operasi yang popular di pasaran, seperti : Symbian, Palm OS, Linux, Android, dan Windows Mobile.

\section{ANDROID}

Android merupakan sistem operasi telepon seluler yang tumbuh di tengah sistem operasi lainnya yang berkembang dewasa ini. Sistem Operasi lainnya seperti Windows Mobile, iOS-iPhone, Symbian, dan masih banyak lagi juga menawarkan kekayaan isi dan keoptimalan berjalan di atas perangkat keras yang ada. Akan tetapi, sistem operasi yang ada ini berjalan dengan memprioritaskan aplikasi inti yang dibangun sendiri tanpa melihat potensi yang cukup besar dari aplikasi pihak ketiga. Oleh karena itu adanya keterbatasan dari aplikasi pihak ketiga untuk mendapatkan data asli ponsel, berkomunikasi antar proses serta keterbatasan distribusi aplikasi pihak ketiga untuk platform mereka.

\section{E. ALGORITMA DIJKSTRA}

Algoritma ini didasarkan pada representasi adjacency matrix untuk sebuah graph. Algoritma ini tidak hanya menemukan jalur terpendek dari satu verteks tertentu ke verteks lain, tetapi juga jalur terpendek dari verteks tertentu ke semua verteks lain. Algoritma ini sering digunakan pada routing. Algoritma dijkstra mencari lintasan terpendek dalam sejumlah langkah. Algoritma ini menggunakan strategi greedy sebagai berikut :

- Untuk setiap simpul sumber(source) dalam graf, algortima ini akan mencari jalur dengan cost minimum

- antara simpul tersebut dengan simpul lainnya. Algoritma juga dapat digunakan untuk mencari total biaya $(\cos t)$ dari lintasan terpendek yang dibentuk dari sebuah simpul ke sebuah simpul tujuan. Sebagai contoh, bila simpul pada graf merepresentasikan kota dan bobot sisi merepresentasikan jarak antara 2 kota yang mengapitnya, maka algoritma Dijkstra dapat digunakan untuk mencari rute terpendek antara sebuah kota dengan kota lainnya.

\section{F. BASIS DATA}

Basis Data dapat didefinisikan dalam berbagai sudut pandang seperti berikut :

1. Himpunan kelompok data yang saling berhubungan yang diorganisasi sedemikian rupa sehingga kelak dapat dimanfaatkan dengan cepat dan mudah.

2. Kumpulan data yang saling berhubungan yang disimpan secara bersama sedemikian rupa tanpa pengulangan (redudancy) yang tidak perlu, untuk memenuhi kebutuhan.

Komponen dari basis data adalah entitas dan atribut.Berikut adalah daftar entitas yang akan dirancang dalam basis data penelitian ini, seperti yang ditunjukkan pada Tabel 1.

TABEL 1 Daftar Entitas yang terlibat

\begin{tabular}{|l|l|l|}
\hline No. & Nama Entitas & Keterangan \\
\hline 1. & Agen & $\begin{array}{l}\text { Entitas yang berisi mengenai informasi } \\
\text { agen travel dan bus yang terdapat di } \\
\text { wilayah semarang. }\end{array}$ \\
\hline 2. & Jenis Agen & $\begin{array}{l}\text { Entitas yang berisi mengenai jenis agen } \\
\text { yang akan dimuat dan disimpan dalam } \\
\text { sistem }\end{array}$ \\
\hline 3. & Profil & $\begin{array}{l}\text { Entitas yang berisi mengenai profil agen } \\
\text { travel dan bus. }\end{array}$ \\
\hline 4. & Rute Agen & $\begin{array}{l}\text { Entitas yang memuat informasi tentang } \\
\text { rute tujuan agen travel dan bus di wilayah } \\
\text { semarang. }\end{array}$ \\
\hline 5. & Jenis Rute & $\begin{array}{l}\text { Entitas yang memuat semuat rute tujuan } \\
\text { yang bisa dilayani oleh sistem }\end{array}$ \\
\hline 6. & Jalur & $\begin{array}{l}\text { Entitas yang berisi mengenai mode jalur } \\
\text { yang bisa dilewati ketika melakukan } \\
\text { pencarian agen tujuan, contohnya tol atau } \\
\text { jalan raya. }\end{array}$ \\
\hline 7. & Jelajah & $\begin{array}{l}\text { Entitas yang berisi mengenai mode jelajah } \\
\text { yang bisa dilakukan ketika melakukan } \\
\text { pencarian agen tujuan. }\end{array}$ \\
\hline 8. & Opsi Map & $\begin{array}{l}\text { Entitas yang berisi informasi mengenai } \\
\text { informasi yang rinci ketika pengguna } \\
\text { melakukan pencarian }\end{array}$ \\
\hline 10. & $\begin{array}{l}\text { Spesifikasi } \\
\text { Pencarian }\end{array}$ & $\begin{array}{l}\text { Entitas yang berisi mengenai jenis } \\
\text { parameter pencarian yang disediakan } \\
\text { dalam sistem. }\end{array}$ \\
\hline $\begin{array}{l}\text { Entitas yang berisi mengenai spesifikasi } \\
\text { pencarian berdasarkan parameter yang } \\
\text { dilakukan pengguna. }\end{array}$ \\
\hline 9 Parameter
\end{tabular}




\begin{tabular}{|l|l|l|}
\hline 11. & $\begin{array}{l}\text { Lokasi } \\
\text { Perangkat }\end{array}$ & $\begin{array}{l}\text { Entitas yang berisi mengenai informasi } \\
\text { lokasi perangkat pengguna ketika } \\
\text { melakukan pencarian }\end{array}$ \\
\hline
\end{tabular}

Tabel 2 berikut ini adalah atribut dari entitas agen.

TABEL 2 Atribut dari entitas agen

\begin{tabular}{|c|c|c|}
\hline Nama & Tipe & Keterangan \\
\hline id_agen & TEXT & ID Agen, Primary key \\
\hline id_jenis & INTEGER & ID Jenis agen, Foreign Key \\
\hline nama_agen & TEXT & Nama agen \\
\hline lat_lokasi & INTEGER & Latitude agen \\
\hline long_lokasi & INTEGER & Longitude agen \\
\hline
\end{tabular}

Tabel 3 berikut ini adalah atribut dari entitas jenis agen.

TABEL 3 Atribut dari entitas jenis agen

\begin{tabular}{|c|c|c|}
\hline Nama & Tipe & Keterangan \\
\hline id_jenis & INTEGER & ID jenis, Primary $k e y$ \\
\hline Jenis_agen & TEXT & Jenis agen \\
\hline
\end{tabular}

Tabel 4 berikut ini adalah atribut dari entitas profil.

TABEL 4 Atribut dari entitas profil

\begin{tabular}{|c|c|c|}
\hline Nama & Tipe & Keterangan \\
\hline id_profil & TEXT & ID profil, Primary key \\
\hline id_agen & TEXT & ID agen, Foreign key \\
\hline alamat_agen & TEXT & Alamat agen \\
\hline phone_agen_satu & TEXT & Telepon pertama agen \\
\hline phone_agen_dua & TEXT & Telepon kedua agen \\
\hline
\end{tabular}

Tabel 5 berikut ini adalah atribut dari entitas rute dari agen bus dan travel.

TABEL 5 Atribut dari entitas rute

\begin{tabular}{|c|c|c|}
\hline Nama & Tipe & Keterangan \\
\hline id_rute & INTEGER & ID rute, Primary key \\
\hline id_agen & TEXT & ID agen, Foreign key \\
\hline asal_rute & TEXT & Rute asal \\
\hline Id_tujuan_rute & INTEGER & ID rute tujuan, Foreign Key \\
\hline flag & INTEGER & Penanda tujuan rute \\
\hline
\end{tabular}

Table 6 berikut ini adalah atribut dari entitas jenis rute

TABEL 6 Atribut dari entitas jenis rute

\begin{tabular}{|c|c|c|}
\hline Nama & Tipe & Keterangan \\
\hline id tujuan_rute & INTEGER & ID jalur, Primary key \\
\hline Tujuan_rute & TEXT & Rute tujuan agen \\
\hline
\end{tabular}

Tabel 7 berikut ini adalah atribut dari entitas jalur.

TABEL 7 Atribut dari entitas jalur

\begin{tabular}{|c|c|c|}
\hline Nama & Tipe & Keterangan \\
\hline id jalur & INTEGER & ID jalur, Primary key \\
\hline mode_jalur & TEXT & Mode jalur \\
\hline
\end{tabular}

Tabel 8 berikut ini adalah atribut dari entitas jelajah .

TABEL 8 Atribut dari entitas jelajah

\begin{tabular}{|c|c|c|}
\hline Nama & Tipe & Keterangan \\
\hline id_jelajah & INTEGER & ID jelajah, Primary key \\
\hline mode_jelajah & TEXT & Mode jelajah \\
\hline
\end{tabular}

Tabel 9 berikut ini adalah atribut entitas opsi map.

TABEL 9 Atribut dari entitas tabel opsi map

\begin{tabular}{|c|c|c|}
\hline Nama & Tipe & Keterangan \\
\hline id_opsi map & INTEGER & ID jalur, Primary key \\
\hline id_spesifikasi & INTEGER & ID spesifikasi, Foreign Key \\
\hline id_lokasi_perangkat & INTEGER & ID lokasi perangkat pengguna, \\
& & Foreign Key \\
\hline id_jelajah & INTEGER & ID jelajah, Foreign Key \\
\hline id_jalur & INTEGER & ID jalur, Foreign Key \\
\hline
\end{tabular}

Tabel 10 berikut ini adalah atribut entitas parameter pencarian.

TABEL 10 Atribut dari entitas tabel parameter pencarian

\begin{tabular}{|c|c|c|}
\hline Nama & Tipe & Keterangan \\
\hline$\underline{\text { id param }}$ & INTEGER & ID parameter, Primary key \\
\hline Jenis parameter & TEXT & Jenis parameter \\
\hline
\end{tabular}

Tabel 11 berikut ini adalah atribut entitas spesifikasi pencarian.

TABEL 11 Atribut dari entitas tabel spesifikasi pencarian

\begin{tabular}{|c|c|c|}
\hline Nama & Tipe & Keterangan \\
\hline id_spesifikasi & INTEGER & ID spesifikasi, Primary key \\
\hline id_param & INTEGER & ID parameter, Foreign Key \\
\hline jenis_spesifikasi & TEXT & $\begin{array}{c}\text { Spesifikasi pencarian berdasarkan } \\
\text { parameter yang dipilih }\end{array}$ \\
\hline
\end{tabular}

Tabel 12 berikut ini adalah atribut entitas lokasi perangkat.

TABEL 12 Atribut dari entitas tabel lokasi perangkat

\begin{tabular}{|c|c|c|}
\hline Nama & Tipe & Keterangan \\
\hline id lokasi_perangkat & INTEGER & $\begin{array}{c}\text { ID lokasi perangkat, } \text { Primary } \\
\text { key }\end{array}$ \\
\hline lat_pencarian & INTEGER & Latitude pencarian \\
\hline long_pencarian & INTEGER & Longitude pencarian \\
\hline
\end{tabular}

\section{ANALISA DAN PERANCANGAN SISTEM}

\section{A. TAHAPAN PENGEMBANGAN METODOLOGI}

Terdapat beberapa tahapan yang dilakukan dalam menyusun sebuah perangkat lunak. Metode Waterfall adalah suatu proses pengembangan perangkat lunak berurutan, dimana kemajuan dipandang sebagai terus mengalir ke bawah (seperti air terjun) melewati fase - fase perencanaan, permodelan, implementasi (konstruksi), dan pengujian. Berikut adalah gambar pengembangan perangkat lunak atau linear. Pada Gambar 2 berikut merupakan tahapan metode Waterfall.

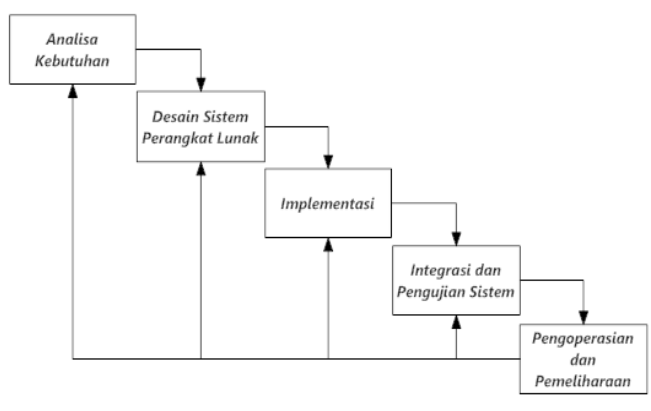

Gambar 2 Metode Waterfall 


\section{B. DESAIN PERANGKAT LUNAK}

Permodelan perangkat lunak digunakan untuk memberikan tahapan yang jelas dalam pembuatan perangkat lunak. Berikut ini adalah permodelan yang digunakan dalam perangkat lunak, yaitu:

\section{DIAGRAM ALIR DATA}

Diagram alir data merupakan perangkat - perangkat analisis dan perancangan yang terstruktur sehingga memungkinkan analis sistem memahami sistem dan subsistem secara visual sebagai suatu rangkaian aliran data yang saling berkaitan.

Diagram konteks merupakan tingkatan tertinggi dalam diagram aliran data dan hanya memuat satu proses, serta menunjukkan sistem secara keseluruhan. Proses tersebut diberi nomor nol. Semua entitas eksternal yang ditunjukkan pada diagram konteks berikut aliran data-aliran data utama menuju dan dari sistem.

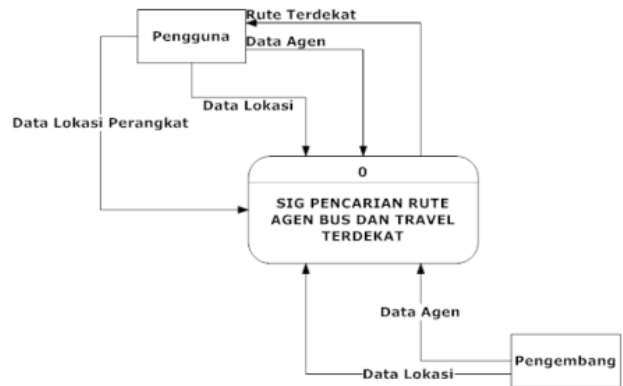

Gambar 3 Diagram Konteks

Gambar 3 menunjukkan diagram konteks dari SIG pencarian lokasi agen terdekat. Diagram tersebut menjelaskan bahwa sistem memiliki menggunakan 2 buah entitas, yaitu pengguna dan pengembang. Ketika pengguna melakukan instalisasi aplikasi untuk pertama kalinya, sistem akan menginisiasi semua data agen dan data lokasi agen di wilayah Kota Semarang yang telah dimasukkan oleh pengembang. Data agen sendiri memuat informasi agen, seperti nama agen, alamat agen, rute agen, dan nomor telepon agen yang dapat dihubungi. Sedangkan Data lokasi memuat informasi letak agen bus dan travel. Data agen dan data lokasi yang telah dimasukkan tadi dapat dikelola oleh pegguna. Pengguna juga dapat melakukan proses pencarian lokasi agen terdekat dengan memberikkan data lokasi perangkat pengguna ke sistem. Untuk detail dari diagram konteks dibuatlah diagram alir data level nol dan satu. Pada diagram alir data level nol, aplikasi ini memiliki 6 buah proses seperti yang ditunjukkan pada Gambar 4.

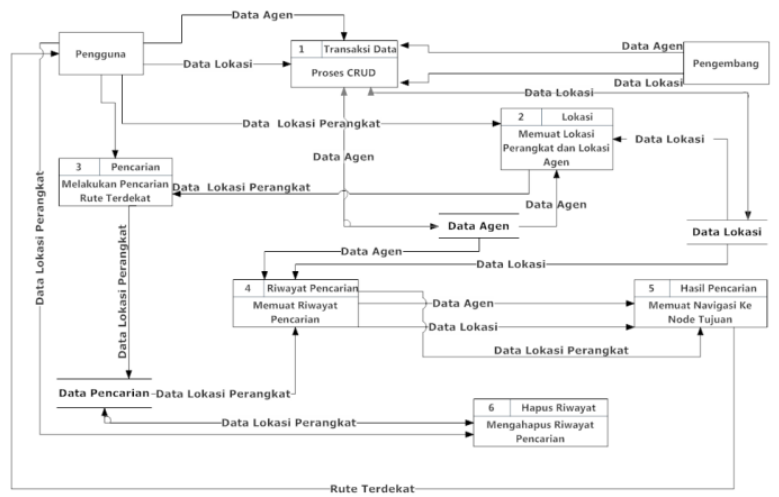

Gambar 4 Diagram Alir Data Level Nol
Kegiatan yang dilakukan pada proses 1 adalah proses CRUD. Proses ini merupakan proses dimana pengguna dan pengembang dapat melakukan pengelolaan data agen dan data lokasi. Data - data ini akan disimpan dalam media penyimpanan data agen dan data lokasi. Proses ini dapat dilihat dengan jelas pada Gambar 5.

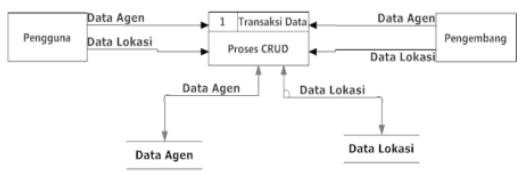

Gambar 5 Proses CRUD

Untuk menjelaskan lebih rinci dari proses ini, maka dibuatlah diagram alir data level satu. Gambar 6 berikut menjelaskan proses kelola data yang dapat dilakukan oleh pengguna dan pengembang.

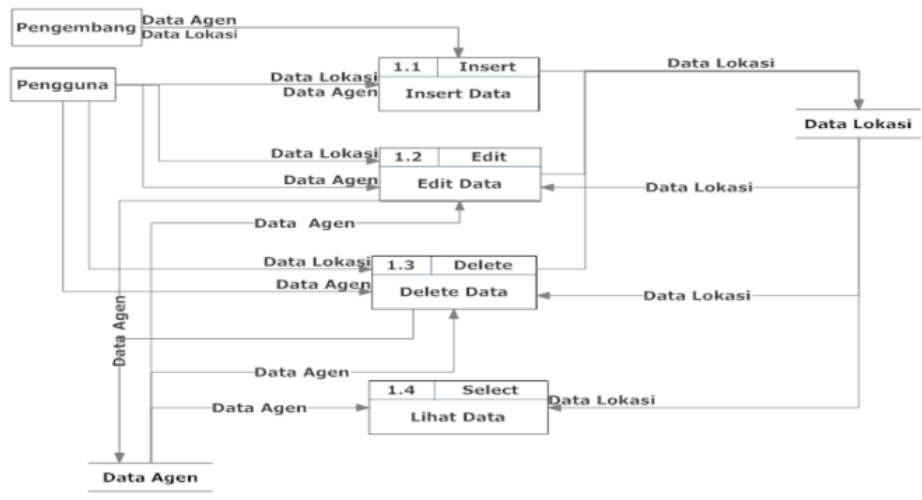

Gambar 6 Diagram Alir Data Level Satu Proses CRUD

Kegiatan yang dilakukan pada proses 1.1 adalah proses insert data. Proses ini merupakan proses dimana pengembang dan pengguna dapat memasukkan data agen dan data lokasi setiap agen ke dalam sistem, yang kemudian disimpan dalam media penyimpanan data agen dan data lokasi. Proses ini dapat dilihat lebih jelas pada Gambar 7.

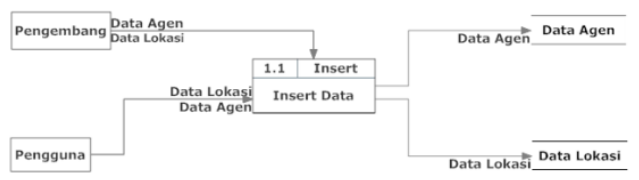

Gambar 7 Proses Insert Data

Kegiatan yang dilakukan pada proses 1.2 adalah proses edit data. Proses ini merupakan proses dimana pengguna data mengubah data agen dan data lokasi setiap agen. Proses ini dapat dilihat lebih jelas pada Gambar 8.

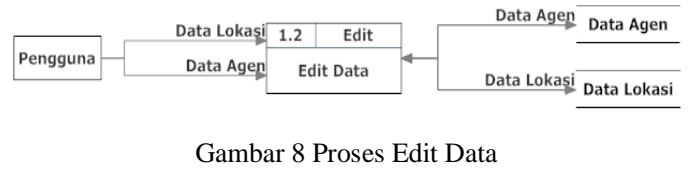

Kegiatan yang dilakukan pada proses 1.3 merupakan proses delete data. Proses ini merupakan proses dimana pengguna dapat menghapus data agen dan data lokasi. Proses ini dapat dilihat lebih jelas pada Gambar 9.

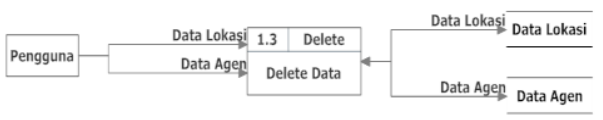

Gambar 9 Proses Delete Data 
Dan pada proses 1.4 yang merupakan proses lihat data, dimana data agen dan data lokasi akan dimuat ke sistem, agar lebih mudah dalam pengelolaannya. Proses ini dapat dilihat lebih jelas pada Gambar 10.

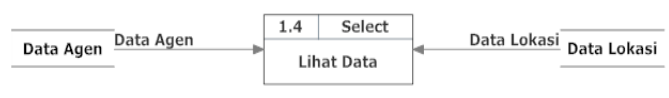

Gambar 10 Proses Lihat Data

Selanjutnya pada proses 2 yang merupakan proses memuat lokasi perangkat dan lokasi agen. Proses ini merupakan proses dimana data lokasi perangkat pengguna akan dimuat ke dalam sistem yang akan digunakan dalam proses 3 yang merupakan proses melakukan pencarian lokasi agen terdekat. Untuk lebih jelasnya proses ini dapat dilihat pada Gambar 11

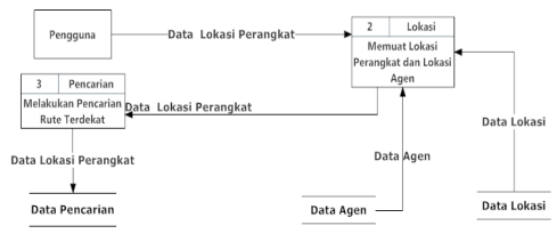

Gambar 11 Proses Memuat Lokasi Perangkat dan Lokasi Agen serta Proses melakukan pencarian lokasi agen terdekat

Selanjutnya pada proses 4 yang merupakan proses memuat riwayat pencarian. Proses ini merupakan proses dimana data lokasi pencarian, data agen,dan data lokasi akan dimuat ke dalam sistem. Data - data tersebut digunakan untuk pencarian lokasi agen terdekat yang hasilnya akan dimuat ke dalam proses 5 yaitu proses memuat navigasi ke node tujuan. Untuk lebih jelasnya proses ini dapat dilihat pada Gambar 12.

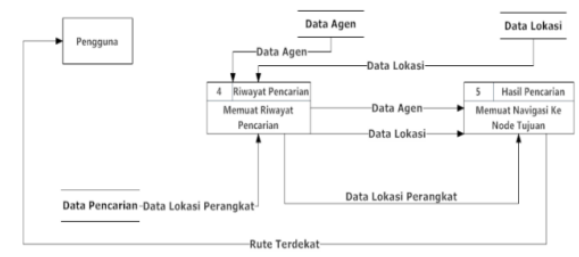

Gambar 12 Proses Memuat Riwayat Pencarian dan Memuat Navigasi Ke Node Tujuan

\section{DIAGRAM RELASI ENTITAS}

Diagram Relasi Entitas adalah suatu model untuk menjelaskan hubungan antar data dalam basis data bedasarkan objek - objek dasar data yang mempunyai hubungan antar relasi seperti yang ditunjukkan pada Gambar 6 dan Gambar 7.

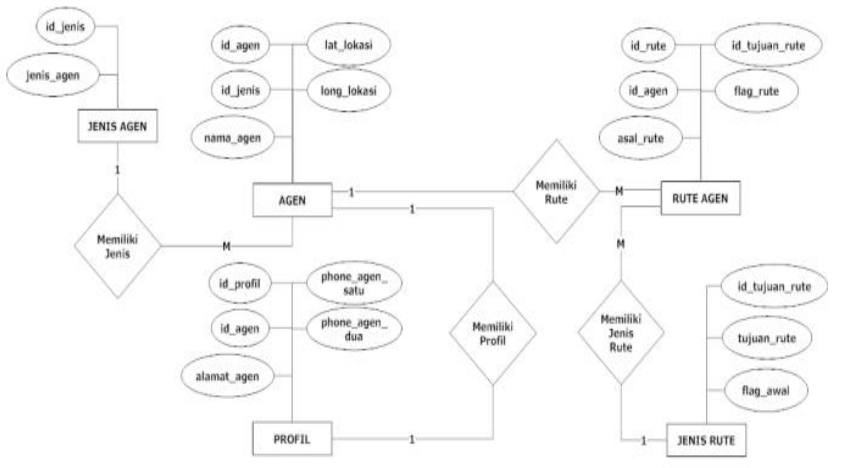

Gambar 13 Diagram Relasi Entitas SIG Pencarian Rute Agen Travel dan Bus Terdekat Bagian 1

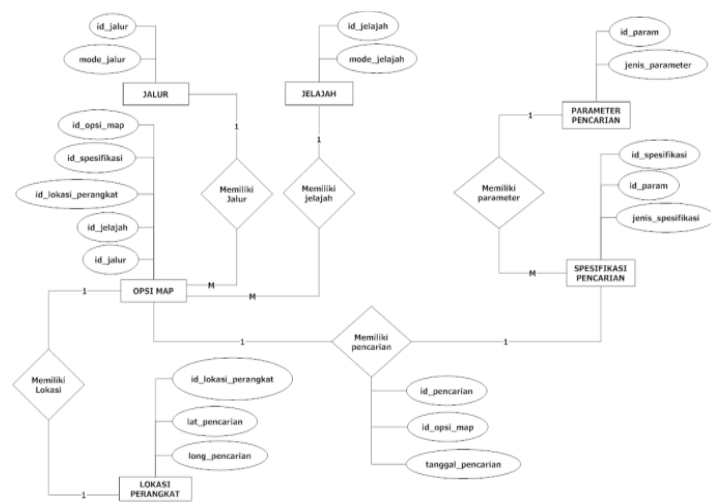

Gambar 14 Diagram Relasi Entitas SIG Pencarian Rute Agen Travel dan Bus Terdekat Bagian 2

Pada Gambar 13 dan Gambar 14 menunujukkan diagram relasi dari SIG yang akan direpresentasikan. Terdapat beberapa relasi yang terjadi pada tabel - tabel yang telah dibuat. Berikut adalah beberapa relasi yang terdapat dalam aplikasi ini, yaitu :

1. Relasi Entitas Agen dan Entitas Profil (1:1)

2. Relasi Entitas Agen dan Entitas Rute Agen (1:M)

3. Relasi Entitas Agen dan Entitas Jenis Agen (1:M)

4. Relasi Entitas Rute Agen dan Entitas Jenis Rute (1:M)

5. Relasi Entitas Opsi Map dan Entitas Jelajah (1:M)

6. Relasi Entitas Opsi Map dan Entitas Jalur (1:M)

7. Relasi Entitas Opsi Map dan Entitas Lokasi Perangkat $(1: 1)$

8. Relasi Entitas Spesifikasi Pencarian dan Entitas Parameter Pencarian (1:M)

9. Relasi Entitas Spesifikasi Pencarian dan Opsi Map (1:1)

\section{SPESIFIKASI PERANGKAT LUNAK DAN PERANGKAT KERAS}

Dalam pengembangan aplikasi ini diperlukan spesifikasi perangkat lunak dan perangkat keras dengan beberapa kriteria yang telah ditentukan. Berikut ini adalah spesifikasi perangkat lunak yang digunakan dalam pengembangan aplikasi ini, yaitu:

1. Microsoft Windows 7 Professional

2. Sublime Text Build 3059

3. Android SDK (Software Development Kit)

4. SQLite

5. Node.js

6. Genymotion

Sedangkan untuk spesifikasi perangkat keras yang digunakan dalam penelitian ini,yaitu:

1. Processor Intel Core i3-330M (2.13 GHz 3MB L3 cache)

2. RAM 2,00 GB

3. Monitor 14.0" HD LED LCD

4. Harddisk 320 GB Toshiba

5. Intel HD Graphics $762 \mathrm{MB}$

6. Mouse dan Keyboard

7.

\section{HASIL DAN PEMBAHASAN}

\section{A. IMPLEMENTASI}

Bagian utama dari tahapan implementasi adalah penjabaran modul yang dibuat menjadi sintaks pemrograman. Berikut adalah Tabel 13 yang menjelaskan modul - modul dari aplikasi pencarian rute agen travel dan bus terdekat ini. 
TABEL 13 Tabel Definisi Modul Perangkat Lunak

\begin{tabular}{|c|l|l|}
\hline No & \multicolumn{1}{|c|}{ Nama Modul } & \multicolumn{1}{|c|}{ Keterangan } \\
\hline 1. & Map & $\begin{array}{l}\text { Modul ini berisi fungsi }- \text { fungsi yang } \\
\text { berkaitan dengan data yang akan dimuat di } \\
\text { peta }\end{array}$ \\
\hline 2. & Agen & $\begin{array}{l}\text { Modul ini berisi fungsi }- \text { fungsi yang } \\
\text { berkaitan dengan kelola data agen. }\end{array}$ \\
\hline 3. & Riwayat & $\begin{array}{l}\text { Modul ini berisi fungsi }- \text { fungsi yang } \\
\text { berkaitan dengan riwayat pencarian pengguna. }\end{array}$ \\
\hline 4. & Tentang aplikasi & $\begin{array}{l}\text { Modul ini berkaitan dengan informasi tentang } \\
\text { aplikasi, dan fitur pengosongan riwayat. }\end{array}$ \\
\hline
\end{tabular}

Pada aplikasi pencarian lokasi terdekat agen travel dan bus dengan metode Dijkstra ini, pengambilan data lokasi menggunakan fitur GPS yang disediakan perangkat pengguna. Pengguna dapat mengaktifikan fitur GPS ini pada menu pengaturan atau setting pada perangkat bergerak, dalam hal ini perangkat bergerak dengan sistem operasi Android. Implementasi pengaturan GPS ini dapat dilihat pada Gambar 15.

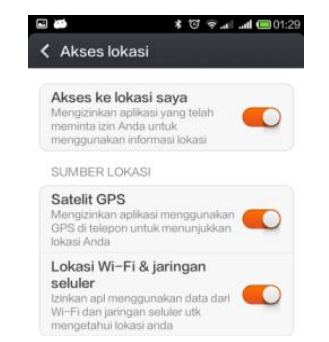

Gambar 15 Implementasi GPS

Penggunaan fitur GPS ini digunakan untuk keakuratan dalam pengambilan data lokasi perangkat pengguna. Pada Gambar 15 diatas, terlihat pengguna menyalakan fitur Satelit GPS dan fitur Lokasi Wi-Fi dan Jaringan Seluler. Apabila kedua fitur ini tidak digunakan maka aplikasi tidak dapat melakukan pencarian rute agen travel atau bus terdekat, seperti yang ditunjukkan pada Gambar 16.

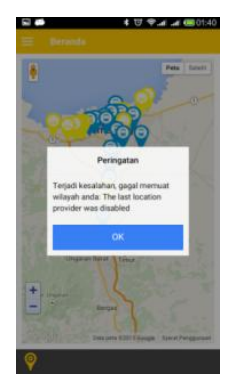

Gambar 16 Peringatan Apabila Fitur Akses Lokasi Tidak Dinyalakan

Antarmuka halaman beranda merupakan halaman dimana pengguna pertama kali masuk ke dalam sistemAntarmuka beranda ini dapat dilihat pada Gambar 17.

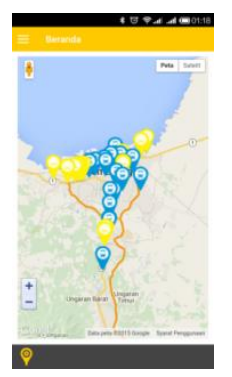

Gambar 17 Antarmuka Beranda
Pada antarmuka beranda diatas, antarmuka menunjukkan lokasi agen yang telah dimasukkan dalam basisdata. Untuk agen bus ditunjukkan dengan penanda berwarna kuning, dan agen travel ditunjukkan dengan penanda berwarna biru. Untuk mendukung tujuan penelitian ini, aplikasi ini menyediakan fitur - fitur pencarian. Untuk memunculkan menu pencarian tersebut, pengguna dapat men - tap ikon penanda lokasi di pojok kiri bawah. Berikut ini adalah fitur - fitur yang terdapat pada menu beranda, yaitu:

1. Lokasi Saya

Fitur lokasi saya mempunyai fungsi untuk menentukan posisi pengguna berada. Untuk menggunakan fitur ini pengguna dapat men - tap ikon penanda lokasi di pojok kiri bawah, dan memilih fitur lokasi saya, seperti yang ditunjukkan pada Gambar 18.

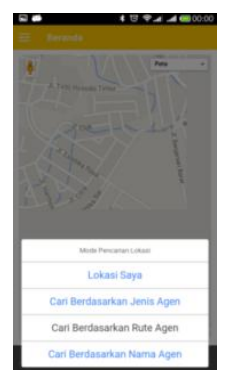

Gambar 18 Menu Pencarian Rute Terdekat

Pada fitur lokasi saya, pengguna dapat mengetahui lokasinya pada saat itu juga di peta yang terdapat pada halaman berandaImplementasi dari fitur lokasi saya dapat dilihat pada Gambar 19.

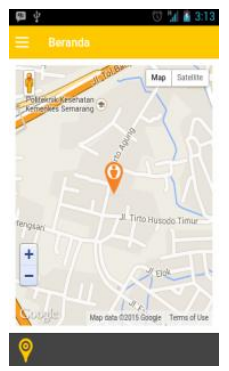

Gambar 19 Fitur Lokasi Saya Pada Antarmuka Beranda

\section{Fitur Pencarian Lokasi Agen Terdekat}

Selanjutnya, untuk melakukan pencarian lokasi agen terdekat, pengguna dapat memilih salah satu dari fitur pencarian sesuai kebutuhan. Berikut ini adalah pencarian lokasi agen berdasarkan parameter pencarian yang disediakan oleh aplikasi, yaitu :

a. Pencarian Lokasi Agen Terdekat Berdasarkan Jenis Agen

Pada fitur pencarian berdasarkan jenis agen, pengguna akan dihadapkan pada form pencarian berdasarkan jenis agen, dimana pengguna diminta memilih salah satu jenis agen dan rute tujuan yang diinginkan untuk mendapatkan lokasi agen terdekat. Berikut ini adalah contoh dari fitur pencarian lokasi agen terdekat berdasarkan jenis agen yang dapat dilihat pada Gambar 20. 


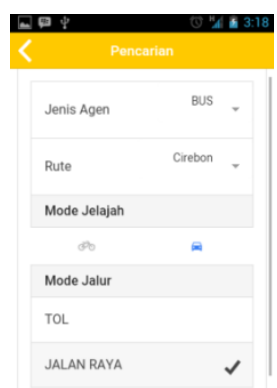

Gambar 20 Implementasi Fitur Pencarian Berdasarkan Jenis Agen

Pada Gambar 20 diatas pengguna melakukan pencarian dengan parameter jenis agen bus. Implementasi dari hasil pencarian berdasarkan parameter jenis agen ini dapat dilihat pada Gambar 21.

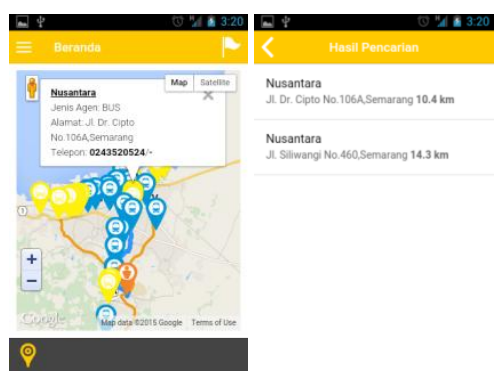

Gambar 21 Hasil Pencarian Lokasi Agen Terdekat Berdasarkan Jenis Agen

b. Pencarian Lokasi Agen Terdekat Berdasarkan Rute Agen

Untuk mendapatkan lokasi agen terdekat dari lokasi pengguna berdasarkan rute tujuan, pengguna hanya perlu memasukkan rute tujuan yang dituju. Implementasi dari fitur pencarian lokasi agen terdekat berdasarkan rute agen ini dapat dilihat pada Gambar 24.

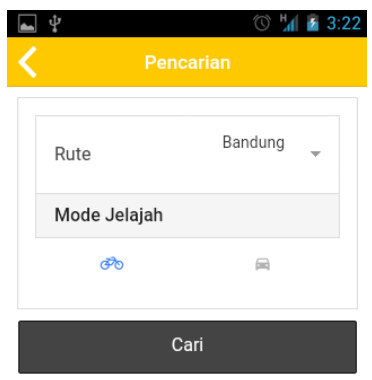

Gambar 24 Implementasi Fitur Pencarian Berdasarkan Rute Agen

Hasil dari pencarian lokasi agen dengan parameter bersdasarkan rute perjalanan bandung ini dapat dilihat pada Gambar 25.

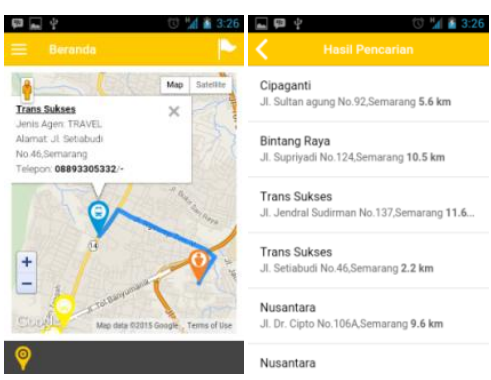

Gambar 25 Hasil Pencarian Lokasi Agen Terdekat Berdasarkan Rute Agen c. Pencarian Lokasi Agen Berdasarkan Nama Agen

Pencarian lokasi agen berdasarkan nama agen dilakukan dengan memasukkan nama agen tujuan, dan aplikasi akan memuat semua lokasi agen yang serupa kemudian sistem akan mencari rute lokasi agen terdekat. Implementasi dari pencarian lokasi agen berdasarkan nama agen ini dapat dilihat pada Gambar 26.

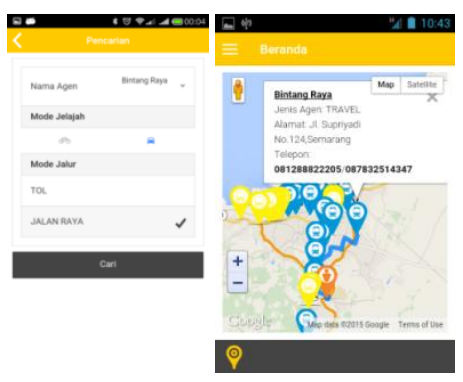

Gambar 26 Implementasi dan Hasil Fitur Pencarian Berdasarkan Nama Agen

\section{B. PENGUJIAN}

Pada tahap ini dilakukan pengujian sistem dengan menggunakan metode white - box. Pengujian white - box adalah metode pengujian perangkat lunak yang menekankan pada fungsionalitas dari sebuah perangkat lunak dengan mengetahui bagaimana struktur di dalam perangkat lunak tersebut. Berikut tahap pengujian perangkat lunak.

\section{PENGUJIAN PADA MODUL MAP}

Fungsi - fungsi yang diujikan pada modul map, dapat dilihat pada Tabel 14.

TABEL 14 Tabel Pengujian Pada Modul Map

\begin{tabular}{|c|c|c|c|}
\hline Nama Fungsi & $\begin{array}{c}\text { Bentuk } \\
\text { Pengujian }\end{array}$ & $\begin{array}{l}\text { Hasil yang } \\
\text { diharapkan }\end{array}$ & $\begin{array}{c}\text { Hasil } \\
\text { Pengujian }\end{array}$ \\
\hline Initialize() & $\begin{array}{l}\text { Masuk ke dalam } \\
\text { halaman beranda } \\
\text { dimana Google } \\
\text { Map API akan } \\
\text { dimuat }\end{array}$ & $\begin{array}{l}\text { Google Map API } \\
\text { berhasil dimuat } \\
\text { dalam aplikasi }\end{array}$ & Berhasil \\
\hline centerOnMe() & $\begin{array}{l}\text { Masuk ke dalam } \\
\text { halaman beranda } \\
\text { dimana Google } \\
\text { Map API akan } \\
\text { dimuat }\end{array}$ & $\begin{array}{l}\text { Memuat wilayah } \\
\text { lokasi pengguna } \\
\text { berada dengan } \\
\text { nilai zoom: } 16\end{array}$ & Berhasil \\
\hline mapCreated() & $\begin{array}{l}\text { Memasukkan data } \\
\text { - data agen } \\
\text { berdasarkan } \\
\text { jenisnya }\end{array}$ & $\begin{array}{l}\text { Memuat penanda } \\
\text { agen di map }\end{array}$ & Berhasil \\
\hline allAgenOnMap() & $\begin{array}{l}\text { Masuk pada } \\
\text { halaman beranda }\end{array}$ & $\begin{array}{l}\text { Fungsi ini dapat } \\
\text { dipanggil untuk } \\
\text { memunculkan } \\
\text { penanda tiap agen } \\
\text { bus dan travel }\end{array}$ & Berhasil \\
\hline showActionSheet() & $\begin{array}{l}\text { Men - tap tombol } \\
\text { ikon fitur } \\
\text { pencarian di } \\
\text { sebelah kiri pojok } \\
\text { bawah dari } \\
\text { halaman beranda }\end{array}$ & $\begin{array}{l}\text { Menampilkan } \\
\text { actionsheet fitur } \\
\text { pencarian }\end{array}$ & Berhasil \\
\hline showModalCari() & $\begin{array}{l}\text { Melakukan } \\
\text { pengujian } \\
\text { terhadap salah } \\
\text { satu menu } \\
\text { pencarian }\end{array}$ & $\begin{array}{l}\text { Berhasil } \\
\text { menampilkan } \\
\text { modal berisi form } \\
\text { pencarian lokasi } \\
\text { agen }\end{array}$ & Berhasil \\
\hline setJelajah() dan & $\begin{array}{l}\text { Melakukan } \\
\text { pengujian }\end{array}$ & $\begin{array}{l}\text { Nilai dari } \\
\text { masing - }\end{array}$ & Berhasil \\
\hline
\end{tabular}




\begin{tabular}{|c|c|c|c|}
\hline Nama Fungsi & $\begin{array}{c}\text { Bentuk } \\
\text { Pengujian }\end{array}$ & $\begin{array}{l}\text { Hasil yang } \\
\text { diharapkan }\end{array}$ & $\begin{array}{c}\text { Hasil } \\
\text { Pengujian }\end{array}$ \\
\hline isJelajah() & $\begin{array}{l}\text { terhadap mode } \\
\text { jelajah yang } \\
\text { terdapat pada } \\
\text { form pencarian }\end{array}$ & $\begin{array}{l}\text { masing mode } \\
\text { jelajah berhasil } \\
\text { dimuat }\end{array}$ & \\
\hline saveEmpty() & $\begin{array}{l}\text { Melakukan } \\
\text { pengujian dengan } \\
\text { men - tap tombol } \\
\text { di masing - } \\
\text { masing form } \\
\text { pencarian }\end{array}$ & $\begin{array}{l}\text { Inisiasi form } \\
\text { pencarian }\end{array}$ & Berhasil \\
\hline removeModalCari() & $\begin{array}{l}\text { Men - tap tombol } \\
\text { ikon back pada } \\
\text { form pencarian }\end{array}$ & $\begin{array}{l}\text { Berhasil keluar } \\
\text { dari form } \\
\text { pencarian }\end{array}$ & Berhasil \\
\hline loadRuteByNama() & $\begin{array}{l}\text { Men - tap menu } \\
\text { pencarian lokasi } \\
\text { agen berdasarkan } \\
\text { nama agen terkait }\end{array}$ & $\begin{array}{l}\text { Berhasil } \\
\text { menampilkan } \\
\text { form pencarian } \\
\text { lokasi agen } \\
\text { berdasarkan } \\
\text { nama agen } \\
\text { terkait }\end{array}$ & Berhasil \\
\hline loadRuteByJenis() & $\begin{array}{l}\text { Men - tap menu } \\
\text { pencarian lokasi } \\
\text { agen terdekat } \\
\text { berdasarkan jenis } \\
\text { agen }\end{array}$ & $\begin{array}{l}\text { Berhasil } \\
\text { menampilkan } \\
\text { form pencarian } \\
\text { lokasi agen } \\
\text { terdekat } \\
\text { berdasarkan } \\
\text { jenis agen }\end{array}$ & Berhasil \\
\hline loadRuteByRute() & $\begin{array}{l}\text { Men - tap menu } \\
\text { pencarian lokasi } \\
\text { agen terdekat } \\
\text { berdasarkan rute } \\
\text { agen }\end{array}$ & $\begin{array}{l}\text { Berhasil } \\
\text { menampilkan } \\
\text { form pencarian } \\
\text { lokasi agen } \\
\text { terdekat } \\
\text { berdasarkan } \\
\text { rute tujuan } \\
\text { agen }\end{array}$ & Berhasil \\
\hline hitungJarak() & $\begin{array}{l}\text { Melakukan } \\
\text { pencarian lokasi } \\
\text { agen terdekat } \\
\text { berdasarkan jenis } \\
\text { agen dan rute } \\
\text { tujuan agen }\end{array}$ & $\begin{array}{l}\text { Berhasil } \\
\text { memuat semua } \\
\text { jarak antara } \\
\text { lokasi } \\
\text { pengguna ke } \\
\text { lokasi agen - } \\
\text { agen yang } \\
\text { berkaitan }\end{array}$ & Berhasil \\
\hline navigasiDijkstra() & $\begin{array}{l}\text { Melakukan } \\
\text { pencarian lokasi } \\
\text { agen terdekat } \\
\text { berdasarkan jenis } \\
\text { agen dan rute } \\
\text { tujuan agen }\end{array}$ & $\begin{array}{l}\text { Berhasil } \\
\text { menampilkan } \\
\text { navigasi ke } \\
\text { lokasi agen } \\
\text { tujuan } \\
\text { berdasarkan } \\
\text { informasi yang } \\
\text { dikirimkan dari } \\
\text { fungsi } \\
\text { hitungjarak() }\end{array}$ & Berhasil \\
\hline hitungJarak2() & $\begin{array}{l}\text { Melakukan } \\
\text { pencarian lokasi } \\
\text { agen berdasarkan } \\
\text { nama agen terkait }\end{array}$ & $\begin{array}{l}\text { Berhasil } \\
\text { memuat semua } \\
\text { jarak antara } \\
\text { lokasi } \\
\text { pengguna ke } \\
\text { lokasi agen - } \\
\text { agen yang } \\
\text { berkaitan }\end{array}$ & Berhasil \\
\hline insertCari() & $\begin{array}{l}\text { Melakukan } \\
\text { pencarian lokasi } \\
\text { agen berdasarkan } \\
\text { semua parameter } \\
\text { yang ada }\end{array}$ & $\begin{array}{l}\text { Menyimpan } \\
\text { hasil pencarian } \\
\text { dalam basisdata }\end{array}$ & Berhasil \\
\hline
\end{tabular}

\section{PENGUJIAN PADA MODUL AGEN}

Fungsi - fungsi yang diujikan pada modul agen, dapat dilihat pada Tabel 15.
TABEL 15 Tabel Pengujian Pada Modul Map

\begin{tabular}{|c|c|c|c|}
\hline Nama Fungsi & $\begin{array}{c}\text { Bentuk } \\
\text { Pengujian }\end{array}$ & $\begin{array}{l}\text { Hasil yang } \\
\text { diharapkan }\end{array}$ & $\begin{array}{c}\text { Hasil } \\
\text { Pengujian }\end{array}$ \\
\hline toggleLeft() & $\begin{array}{l}\text { Men - tap } \\
\text { navigasi bar } \\
\text { yang berada } \\
\text { pada menu data } \\
\text { agen }\end{array}$ & $\begin{array}{l}\text { Menu bar berhasil } \\
\text { dimuat }\end{array}$ & Berhasil \\
\hline refreshAgen() & $\begin{array}{l}\text { Memasukan } \\
\text { data agen dan } \\
\text { mengubah data } \\
\text { agen yang telah } \\
\text { tersimpan }\end{array}$ & $\begin{array}{l}\text { Data agen } \\
\text { berhasil ditambah } \\
\text { dan data agen } \\
\text { yang menagalami } \\
\text { perubahan } \\
\text { berhasil diubah }\end{array}$ & Berhasil \\
\hline showTambahDialog() & $\begin{array}{l}\text { Men - tap } \\
\text { tombol tambah } \\
\text { data agen dan } \\
\text { ubah data agen }\end{array}$ & $\begin{array}{l}\text { Modal Form data } \\
\text { agen berhasil } \\
\text { ditampilkan }\end{array}$ & Berhasil \\
\hline exitDialog() & $\begin{array}{l}\text { Men - tap } \\
\text { tombol back } \\
\text { pada modal } \\
\text { form data agen }\end{array}$ & $\begin{array}{l}\text { Keluar dari modal } \\
\text { form data agen }\end{array}$ & Berhasil \\
\hline saveEmpty() & $\begin{array}{l}\text { Men - tap } \\
\text { tombol simpan } \\
\text { dan ubah yang } \\
\text { ada pada } \text { modal } \\
\text { form data agen }\end{array}$ & $\begin{array}{l}\text { Menginisiasi } \\
\text { form tambah data }\end{array}$ & Berhasil \\
\hline getAlamat() & $\begin{array}{l}\text { Melakukan } \\
\text { penambahan } \\
\text { dan } \\
\text { pengubahan } \\
\text { data agen }\end{array}$ & $\begin{array}{l}\text { Konversi alamat } \\
\text { menjadi } \\
\text { koordinat latitude } \\
\text { dan longitude }\end{array}$ & Berhasil \\
\hline doInput() & $\begin{array}{l}\text { Melakukan } \\
\text { penambahan } \\
\text { data agen }\end{array}$ & $\begin{array}{l}\text { Menyimpan } \\
\text { penambahan data } \\
\text { agen }\end{array}$ & Berhasil \\
\hline $\operatorname{doEdit}()$ & $\begin{array}{l}\text { Melakukan } \\
\text { pengubahan } \\
\text { data agen }\end{array}$ & $\begin{array}{l}\text { Menyimpan } \\
\text { pengubahan data } \\
\text { agen }\end{array}$ & Berhasil \\
\hline removeData() & $\begin{array}{l}\text { Men - tap } \\
\text { tombol hapus } \\
\text { data agen }\end{array}$ & $\begin{array}{l}\text { Menghapus data } \\
\text { agen }\end{array}$ & Berhasil \\
\hline editData() & $\begin{array}{l}\text { Men - tap } \\
\text { tombol edit } \\
\text { data agen }\end{array}$ & $\begin{array}{l}\text { Memuat data } \\
\text { agen terkait ke } \\
\text { dalam form }\end{array}$ & Berhasil \\
\hline
\end{tabular}

\section{PENGUJIAN PADA MODUL RIWAYAT}

Fungsi - fungsi yang diujikan pada modul riwayat, dapat dilihat pada Tabel 16.

TABEL 16 Tabel Pengujian Pada Modul Map

\begin{tabular}{|l|l|l|c|}
\hline \multicolumn{1}{|c|}{ Nama Fungsi } & \multicolumn{1}{|c|}{$\begin{array}{c}\text { Bentuk } \\
\text { Pengujian }\end{array}$} & $\begin{array}{c}\text { Hasil yang } \\
\text { diharapkan }\end{array}$ & $\begin{array}{c}\text { Hasil } \\
\text { Pengujian }\end{array}$ \\
\hline mapCreated() & $\begin{array}{l}\text { Men - tap tombol } \\
\text { lihat hasil pada } \\
\text { data pencarian } \\
\text { tertentu }\end{array}$ & $\begin{array}{l}\text { Memuat Google } \\
\text { Map API di } \\
\text { modal } \text { hasil } \\
\text { pencarian }\end{array}$ & Berhasil \\
\hline showMap() & $\begin{array}{l}\text { Men - tap tombol } \\
\text { lihat hasil pada } \\
\text { data pencarian } \\
\text { tertentu }\end{array}$ & $\begin{array}{l}\text { Menampilkan } \\
\text { modal } \text { hasil } \\
\text { pencarian dan } \\
\text { memuat hasil } \\
\text { pencarian }\end{array}$ & Berhasil \\
\hline exitMap() & $\begin{array}{l}\text { Men - tap tombol } \\
\text { back pada modal } \\
\text { hasil pencarian }\end{array}$ & $\begin{array}{l}\text { Keluar dari modal } \\
\text { hasil pencarian }\end{array}$ & Berhasil \\
\hline hitungJarak() & $\begin{array}{l}\text { Men - tap tombol } \\
\text { lihat hasil pada } \\
\text { data pencarian }\end{array}$ & $\begin{array}{l}\text { Memuat semua } \\
\text { jarak antara } \\
\text { lokasi pengguna } \\
\text { ke lokasi agen - }\end{array}$ & Berhasil \\
\hline
\end{tabular}




\begin{tabular}{|l|l|l|c|}
\hline Nama Fungsi & \multicolumn{1}{|c|}{$\begin{array}{c}\text { Bentuk } \\
\text { Pengujian }\end{array}$} & $\begin{array}{c}\text { Hasil yang } \\
\text { diharapkan }\end{array}$ & $\begin{array}{c}\text { Hasil } \\
\text { Pengujian }\end{array}$ \\
\hline navigasiDijkstra() & $\begin{array}{l}\text { tertentu } \\
\text { Men - tap tombol } \\
\text { lihat hasil pada } \\
\text { data pencarian } \\
\text { tertentu }\end{array}$ & $\begin{array}{l}\text { agen yang } \\
\text { berkaitan } \\
\text { menampilkan } \\
\text { navigasi ke lokasi } \\
\text { agen tujuan }\end{array}$ & Berhasil \\
\hline hitungJarak2() & $\begin{array}{l}\text { Melakukan } \\
\text { pencarian lokasi } \\
\text { agen berdasarkan } \\
\text { nama agen terkait }\end{array}$ & $\begin{array}{l}\text { Berhasil memuat } \\
\text { semua jarak } \\
\text { antara lokasi } \\
\text { pengguna ke } \\
\text { lokasi agen } \\
\text { agen yang } \\
\text { berkaitan }\end{array}$ & Berhasil \\
\hline refreshRiwayat() & $\begin{array}{l}\text { Melakukan } \\
\text { pencarian lokasi } \\
\text { agen dengan } \\
\text { berbagai } \\
\text { parameter } \\
\text { pencarian }\end{array}$ & $\begin{array}{l}\text { Memuat data baru } \\
\text { hasil pencarian } \\
\text { yang dilakukan } \\
\text { pengguna }\end{array}$ & Berhasil \\
\hline hapusRiwayat() & $\begin{array}{l}\text { Men - tap tombol } \\
\text { hapus pada data } \\
\text { pencarian tertentu }\end{array}$ & $\begin{array}{l}\text { Menghapus data } \\
\text { terkait dari } \\
\text { riwayat pencarian }\end{array}$ & Berhasil \\
\hline
\end{tabular}

\section{PENGUJIAN PADA MODUL TENTANG}

\section{APLIKASI}

Fungsi - fungsi yang diujikan pada modul tentang aplikasi, dapat dilihat pada Tabel 17.

TABEL 17 Tabel Pengujian Pada Modul Map

\begin{tabular}{|c|l|l|c|}
\hline Nama Pengujian & Bentuk Pengujian & $\begin{array}{c}\text { Hasil yang } \\
\text { diharapkan }\end{array}$ & $\begin{array}{c}\text { Hasil } \\
\text { Pengujian }\end{array}$ \\
\hline pushSettingChange() & $\begin{array}{l}\text { Menggeser toggle } \\
\text { on/off di menu } \\
\text { pengaturan }\end{array}$ & $\begin{array}{l}\text { Menghapus } \\
\text { semua data } \\
\text { pencarian }\end{array}$ & Berhasil \\
\hline
\end{tabular}

\section{PENGOPERASIAN DAN PEMELIHARAAN}

Pada tahap pengoperasian, aplikasi yang telah siap digunakan akan disitrubusikan melalui Google Play Store, yang merupakan layanan distribusi konten untuk pengguna perangkat ber - platform Android. Serta untuk mengantisiapasi perubahan yang disesuaikan dengan permintaan kebutuhan pengguna, baik berkaitan dengan fungsionalitas perangkat lunak ataupun perangkat keras, maka dapat dilakukan pemeliharaan oleh pengembang terhadap aplikasi SIG ini.

\section{KESIMPULAN}

\section{A. KESMIPULAN}

Kesimpulan yang dapat diambil dari penelitian yang telah dilakukan tentang Aplikasi Pencarian Rute Agen Travel dan Bus Terdekat dengan Metode Dijkstra di Wilayah Kota Semarang ini adalah sebagai berikut:

1. Dengan aplikasi pencarian rute agen travel dan bus ini, pengguna dapat dengan mudah menemukan agen berdasarkan parameter yang telah disediakan

2. Dengan menggunakan Google Maps API maka aplikasi dapat memberikan layanan lokasi dengan baik

3. Aplikasi yang dikembangkan dengan menggunakan media penyimpanan lokal Sqlite, memudahkan pengguna dalam mengelola data - data agen.

4. Penggunaan Ionic Framework dan sistem operasi Android dengan minimum versi 4.0, membuat antarmuka aplikasi menjadi lebih menarik dan mudah digunakan oleh pengguna.

5. Metode pencarian yang digunakan, dalam hal ini Dijkstra telah menentukan rute agen terdekat dari lokasi perangkat pengguna dengan membandingkan jarak antara perangkat pengguna ke node - node terkait.

\section{B. SARAN}

Saran yang dapat diambil dari Tugas Akhir ini adalah sebagai berikut:

1. Penambahan fitur pada aplikasi sangat disarankan, semisal penambahan fitur pemesanan tiket langsung bus dan travel, jam keberangkatan armada yang telah agen sediakan, dan tentunya tidak hanya di wilayah semarang saja .

2. Oleh karena digunakannya ionic framework , diharapkan aplikasi pencarian rute agen travel dan bus terdekat ini dapat berjalan di platform lain, seperti iOS, windows phone, dan Blackberry OS.

\section{DAFTAR PUSTAKA}

[1] Riyanto, 2010, Sistem Informasi Geografis Berbasis Mobile, Yogyakarta : GAVA MEDIA

[2] Rachman, S. Nofan Maulana.2012. Sistem Informasi Geografi Pariwisata Kota Yogyakarta Berbasis Android 2.2.Naskah Publikasi Sekolah Tinggi Ilmu Manajemen Informatika dan Komputer

[3] Prahasta, Eddy. 2009. Sistem Informasi Geografis : Konsep-konsep Dasar (Perspektif Geodesi \& Geomatika). Penerbit Informatika, Bandung

[4] Siswanto,2011,Algoritma dan Struktur Data Non Linear dengan Java, Yogyakarta : GRAHA ILMU

[5] Ionic Framework. Online at

http://ionicframework.com/docs/guide/preface.html, diakses pada 17 Desember 2014, 15.00 WIB.

[6] Google Maps JavaScript Api V3. Online at http://developers.google.com/maps/documentation/j avascript/ diakses pada Tanggal 6 Maret 2014, 03.25 WIB.

[7] Kusrini, 2007, Strategi Perancangan dan Pengelolaan Basis Data, Yogyakarta: Andi Offset

[8] Connolly, T., Begg, C. 2010. Database Systems: a practical approach to

design, implementation, and management. 5th

Edition. America: Pearson

Education.

[9] SQLite. Online at

http://www.sqlite.org/about.html, diakses pada 6 maret 2014, 04.00 WIB.

[10] Pressman, Roger S.2001. Software Engineering : A Practitioner's Approach, Fifth Edition. Singapore:The McGraw-Hill Companies, Inc.

[11] Majalah Transportasi. Online at

http://majalahtransportasi.blogspot.com, diakses pada 20 Februari 2015, 20.00 WIB. 